allow for differences in inhalation) and urinary nicotine excretion rate-broadly support this conclusion.

The relevance of standard nicotine and tar deliveries to actual smoking has been questioned. ${ }^{12}$ The relation between nicotine deliveries actually obtained by smokers in the present study and

TABLE III-Mouth nicotine intake estimated by butt analysis and expressed as percentage of delivery expected from standard (machine) yields

\begin{tabular}{cccc}
\hline Cigarette brand & & $\begin{array}{c}\text { Cigarette smoked } \\
\text { in laboratory }\end{array}$ & $\begin{array}{c}\text { 24-hour collection } \\
\text { (mean per cigarette) }\end{array}$ \\
\hline $\begin{array}{l}\text { High-nicotine } \\
\text { Usual brand (medium-nicotine) }\end{array}$ & 109 & 76 \\
Low-nicotine & $\ldots$ & 96 & 96 \\
\end{tabular}

those expected on the basis of the standardised smoking of a machine is therefore of interest (table III). With high- and medium-nicotine brands smoked in the laboratory the predicted yields were close to those actually observed. The predicted yields, however, considerably overestimated the average nicotine yield of both types of cigarette over 24-hour periods of presumably more-normal smoking outside the laboratory. This finding suggests that the criteria used to derive the standard yields of high- and medium-nicotine cigarettes overestimate the intensity with which these cigarettes are actually smoked. Conversely, the same criteria underestimate the nicotine intake from low-nicotine cigarettes, both inside and outside the laboratory.

The changes in smoking behaviour which result in this degree of compensation appear to be complex, since in these subjects nicotine yield was not associated with either per cent puffing time or 24-hour consumption. Changes in inhalation or strength of draw on the cigarette, or both, may have been among the many variables implicated. It is tempting to conjecture that the powerful self-regulation of nicotine intake shown by these results are brought about by central nervous mechanisms that may well include chemoreceptors.

We are grateful to $\mathrm{Mr} \mathrm{E}$ Meredith for carrying out the urine nicotine and cotinine estimations, Mr V R Marsh and Mr G Nixon for technical help, Mrs V Wright for secretarial help, and the Tobacco Research Council for generous financial help.

\section{References}

${ }^{1}$ Health Departments of the UK, Tar and Nicotine Yields of Cigarettes. London, DHSS, 1979.

${ }^{2}$ Ashton, H, and Watson, D W, British Medical fournal, 1970, 3, 679.

${ }^{3}$ Frith, C D, Psychopharmacologia, 1971, 19, 188.

4 Russell, M A H, et al, British Medical fournal, 1973, 4, 512.

${ }^{5}$ Russell, M A H, et al, British Medical fournal, 1975, 2, 414.

6 Turner, J A McM, Sillett, R W, and Ball, K P, Lancet, 1974, 2, 737.

${ }^{7}$ Freedman, S, and Fletcher, C M, British Medical fournal, 1976, 1, 1427

${ }^{8}$ Kozlowski, L T, Jarvik, M E, and Gritz, E R, Clinical Pharmacology and Therapeutics, 1975, 17, 93.

9 Schachter, S, Fournal of Experimental Psychology: General, 1977, 106, 5.

${ }^{10}$ Feyerabend, C, and Russell, M A H, Fournal of Pharmacy and Pharmaco$\log y, 1979, \mathbf{3 1}, 73$.

${ }^{11}$ Beckett, A H, and Triggs, E J, Nature, 1966, 211, 1415.

12 Green, S J, in Smoking Behaviour: Physiological and Psychological In fluences, ed R E Thornton. Edinburgh, Churchill Livingstone, 1978.

(Accepied 28 fune 1979)

\title{
Adverse reactions to frusemide in hospital inpatients
}

\author{
JULIA LOWE, JANE GRAY, D A HENRY, D H LAWSON
}

British Medical fournal, 1979, 2, 360-362

\section{Summary and conclusions}

Out of 2580 medical inpatients included in a drugsurveillance programme, $585(22.7 \%)$ were treated with frusemide. Of these, $123(21 \cdot 0 \%)$ had a total of 177 adverse reactions. The most common were hypovolaemia (85 cases), hyperuricaemia (54), and hypokalaemia (21). Most reactions were mild, and only three patients had potentially life-threatening effects. The incidence of adverse reactions increased significantly with daily dose, occurring in 47 patients $(13.5 \%$ ) given up to $40 \mathrm{mg}, 42$ $(26.3 \%)$ given up to $80 \mathrm{mg}$, and $34(43.6 \%)$ given over $80 \mathrm{mg}(\mathbf{P}<0.001)$. There was no clear association between side effects and a raised blood urea concentration on admission, confirming that treatment with frusemide is not more hazardous in patients with renal failure.

Drug Surveillance Programme, Royal Infirmary, Glasgow

JULIA LOWE, MB, MRCP, medical registrar (present address: Medical School, University of Nottingham, Nottingham NG7 2RD)

JANE GRAY, MB, CHB, research assistant

D A HENRY, MB, MRCP, medical registrar (now lecturer in therapeutics, University of Nottingham, City Hospital, Nottingham NG5 1PB)

D H LAWSON, MD, FRCP, consultant physician
Frusemide is a safe and highly effective diuretic. Nevertheless, in view of the potential seriousness of volume depletion, dosage should probably begin at 20 rather than $40 \mathrm{mg}$ daily.

\section{Introduction}

Frusemide became available for use in the UK in 1964 and rapidly became the most widely used diuretic. Undesired effects include electrolyte disturbance, volume depletion, and hyperuricaemia, ${ }^{1}$ but their true incidence is unknown. We describe the reactions noted in 585 consecutive recipients of frusemide who participated in a drug-surveillance programme.

\section{Patients and methods}

Consecutive patients admitted to general medical wards in the Western Infirmary and Stobhill General Hospital, Glasgow, participated in the study. The methods used were similar to those of the Boston Collaborative Drug Surveillance Programme, of which our programme is an offshoot. ${ }^{2}$ Specially trained nurses (monitors) use standardised self-coding data sheets to record demographic and diagnostic information on admission. When drugs are prescribed a detailed record is kept of the starting and stopping indications, dose given, and presence or absence of any undesired or unintended effect (the adverse reaction). When a suspected adverse reaction is reported 
it is evaluated independently by the prescribing physician and a clinical pharmacologist. Only information accepted by both physicians is included here.

\section{Results}

A total of 2580 medical inpatients were monitored between April 1973 and April $1976 .{ }^{3}$ Of these, $585(22.7 \%)$ were given frusemide. Their average age was 67 years, half were male, and $91(15.6 \%)$ died during their stay. The primary diagnoses on discharge were cardiovascular disease in 348 patients $(59 \%)$, respiratory disease in $94(16 \%)$, alimentary disorders in $18(3 \%)$, and renal disease in $16(3 \%)$. The remaining 109 patients had a wide variety of diagnoses.

Frusemide was given by mouth to 413 patients $(71 \%)$, intravenously to $34(6 \%)$, and by both routes to $138\left(24^{\circ}\right)$. The most common daily dose was $40 \mathrm{mg}$ or less, which was given to 347 patients $(59 \%)$. Of the remainder, $160(27 \%)$ received up to $80 \mathrm{mg}$ and $78(13 \%)$ more than $80 \mathrm{mg} ; 11$ patients received over $250 \mathrm{mg}$ daily. Adverse reactions attributed to frusemide occurred in 123 patients $(21 \%)$. The incidence of reactions was similar in both participating hospitals and was unrelated to sex, diagnosis, route of administration, and coadministration of any other drug. There was no clear-cut relation between adverse effects and the blood urea concentration on admission, but there was a trend towards increased side effects in older patients and those who died. In only the first case was this statistically significant (table I).

TABLE 1-Adverse reactions to frusemide in relation to blood urea concentration on admission, age, and survival

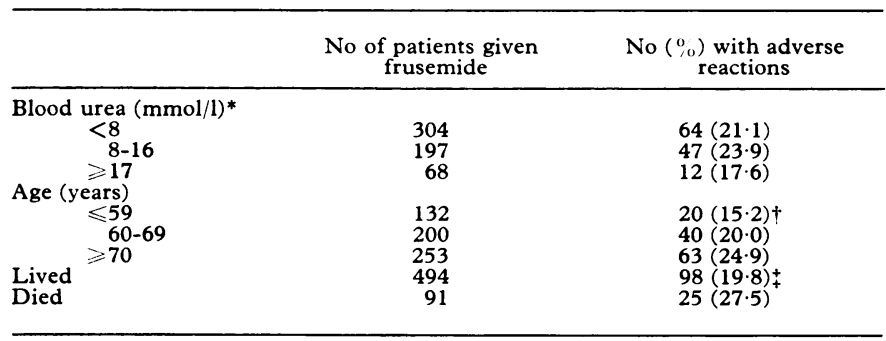

*In 16 cases blood urea concentration was not recorded.

$\dagger \chi_{1}^{2}=5 \cdot 11 ; \mathrm{P}<0.05$ ( $\chi^{2}$ test for trend).

$+\chi_{1}^{2}=2.68 ; P>0.01$.

Conversion: SI to traditional units-Blood urea: $1 \mathrm{mmol} / 1=6 \mathrm{mg} / 100 \mathrm{ml}$.

Table II lists the types of adverse reactions noted. A total of 177 were reported, the most common being volume depletion (manifested clinically or as a raised blood urea concentration), which occurred in 85 patients. The mean rise in blood urea concentration was $11.8 \pm$ SE of mean $0.8 \mathrm{mmol} / 1(71.1 \pm 4.8 \mathrm{mg} / 100 \mathrm{ml})$ and was independent of the concentration on admission. Of the 54 patients who developed hyperuricaemia, 40 also had volume depletion. Clinical gout occurred in only two cases $(0.3 \%)$. Among those with hyperuricaemia the average peak plasma urate concentration was $0.63 \pm \mathrm{SE}$ of mean $0.03 \mathrm{mmol} / 1(10.6 \pm 0.5 \mathrm{mg} / 100 \mathrm{ml})$ (upper limit of normal in our laboratory $0.43 \mathrm{mmol} / \mathrm{l}(7.2 \mathrm{mg} / 100 \mathrm{ml}))$.

Hypokalaemia was reported in 21 patients, 11 female and 10 male. The average fall in serum potassium concentration after beginning frusemide in these patients was $1.4 \mathrm{mmol}(\mathrm{mEq}) / 1$ and the average concentration attained $2.9 \pm \mathrm{SE} 0.1 \mathrm{mmol} / \mathrm{l}$. The mean falls in concentration were similar in those who received and did not receive potassium supplements (see figure). Seventeen of the 21 patients becanie hypokalaemic within 10 days after starting frusemide, 12 of whom were hypokalaemic by day 5 . In five patients the serum

TABLE II-Adverse effects attributed to frusemide*

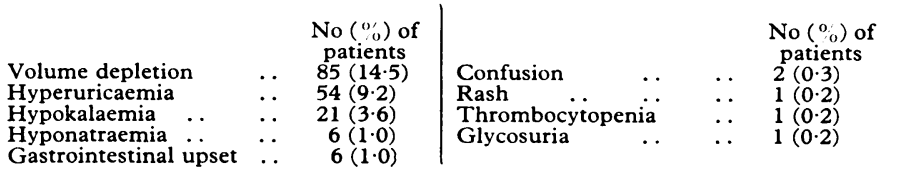

*Some patients suffered more than one adverse effect. potassium concentrations fell below $2.5 \mathrm{mmol} / 1$; two had values below $2.0 \mathrm{mmol} / 1(1.7$ and $1.8 \mathrm{mmol} / \mathrm{l})$. These two patients were among the three in the series whose adverse effects were regarded as potentially life-threatening. Both survived without ill effects.

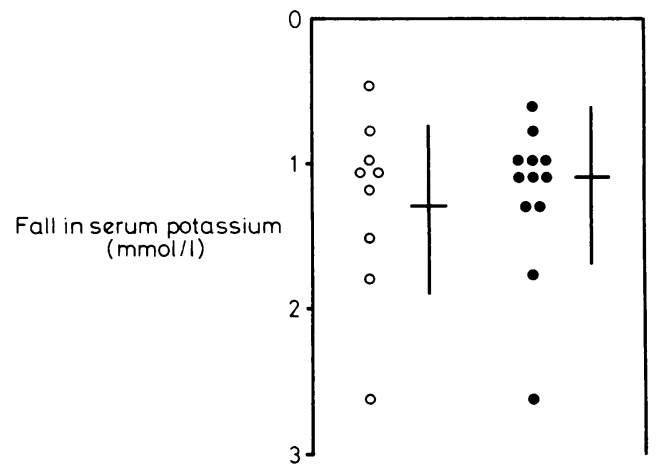

Reductions in serum potassium concentration in 21 patients who became hypokalaemic $(<3.4 \mathrm{mmol}$ $(\mathrm{mEq}) / \mathrm{l})$ after frusemide. $O=$ Patients not given potassium supplements. $=$ Patients given potassium supplements. Bars represent means $\pm S D$.

The incidence of adverse effects was strongly related to daily dose. Side effects occurred in 47 of the 347 patients $(13.5 \%$ ) given $40 \mathrm{mg}$ or less, 42 of the $160(26.3 \%)$ given up to $80 \mathrm{mg}$, and 34 of the 78 $(43.6 \%)$ given over $80 \mathrm{mg}\left(\chi_{1}^{2}=38.36 ; \mathrm{P}<0.001, \chi^{2}\right.$ test for trend). A significant dose effect remained when each of the three main adverse reactions was considered separately (table III). This was most pronounced in the cases of hypovolaemia $\left(\chi_{1}^{2}=52.12 ; \mathrm{P}<0.001\right)$ and hyperuricaemia $\left(\chi_{1}^{2}=28.43 ; \mathrm{P}<0.001\right)$. Hypokalaemia was also doserelated $\left(\chi_{1}^{2}=7.33 ; P<0.01\right)$ but the trend was weaker than for the other two effects.

TABLE III-Incidences of three main adverse effects in patients given different doses of frusemide*

\begin{tabular}{|c|c|c|c|c|}
\hline & & \multicolumn{3}{|c|}{ Daily frusemide dose (mg) } \\
\hline & & $\begin{aligned} & \leqslant 40 \\
(n & =347)\end{aligned}$ & $\begin{array}{l}40-80 \\
(n=160)\end{array}$ & $\begin{array}{c}\geqslant 80 \\
(n=78)\end{array}$ \\
\hline $\begin{array}{l}\text { No }\left({ }^{\circ}\right) \text { with hypokalaemia } \\
\text { No }(0,1) \text { with hyperuricaemia } \\
\text { No }(\%) \text {, } \\
(\%) \text { with hypovolaemia }\end{array}$ & $\begin{array}{l}\ldots \\
\cdots\end{array}$ & $\begin{array}{l}6(1 \cdot 7) \\
18(5 \cdot 2) \\
26(7 \cdot 5)\end{array}$ & $\begin{array}{l}10(6 \cdot 3) \\
16(10 \cdot 0) \\
28(17 \cdot 5)\end{array}$ & $\begin{array}{r}5(6 \cdot 4) \\
20(25 \cdot 6) \\
31(39 \cdot 7)\end{array}$ \\
\hline
\end{tabular}

* Some patients suffered more than one adverse effect.

Significance of trends for increasing incidence with dosage: hypokalaemia $\chi_{1}^{2}=$ $7 \cdot 33, P<0.01 ;$ hyperuricaem
$P<0.001$. ( $\chi^{2}$ test for trend.)

Hyponatraemia (plasma sodium concentration below $130 \mathrm{mmol}$ $(\mathrm{mEq}) / \mathrm{l})$ attributed solely to frusemide was rare and occurred in only six patients. Four of them received doses exceeding $80 \mathrm{mg} /$ day. Alimentary upsets were also rare (six cases), as was confusion, which was associated with dehydration in two elderly patients with cardiac failure (aged 78 and 82 years). One 53-year-old man developed a patchy erythematous rash on his trunk associated with a mild bullous eruption on his fingers 12 days after beginning $40 \mathrm{mg}$ frusemide daily for refractory cardiac oedema. He had moderately severe renal failure with a creatinine clearance of $15 \mathrm{ml} / \mathrm{min}$. A 62-year-old man with no personal or family history of diabetes developed glycosuria attributed to frusemide, which was given to control oedema. Glycosuria remained for at least two months after frusemide was stopped. An 82-year-old woman admitted with acute myocardial infarction complicated by moderate renal impairment developed progressive thrombocytopenia while receiving $80 \mathrm{mg}$ frusemide and $0.25 \mathrm{mg}$ digoxin daily. During eight days of treatment her platelet count fell from $110 \times 10^{9} / 1\left(110000 / \mathrm{mm}^{3}\right)$ to $35 \times 10^{9} / 1\left(35000 / \mathrm{mm}^{3}\right)$. Both drugs were incriminated and withdrawn and the platelet count returned to normal over a few days.

Of the 2580 patients monitored, 85 were admitted partly as a result of drug toxicity. ${ }^{4}$ Although several were receiving frusemide, in no case was the frusemide implicated as a causal or contributory factor. 


\section{Discussion}

We have documented the incidences of adverse events attributed to frusemide in 585 consecutive medical inpatients in two university teaching hospitals. The adverse reactions were reported during ward rounds and were then carefully evaluated by a clinical pharmacologist independently of the attending physicians. Only those reactions thought to be "definitely" or "probably" related to frusemide were included in the analysis. Moreover, since most of the reactions attributed to the drug were biochemical their incidence was related to the frequency of measuring such variables as electrolyte and urate concentrations. Both hospitals participating in the study were particularly interested in diuretic treatment, so that estimates of these variables were made regularly in all recipients.

Reactions were reported in 123 patients $\left(21^{\circ}{ }_{0}\right)$. Most were mild, and only three patients $(0.5 \%$ of recipients) developed life-threatening effects. Adverse reactions were commoner in the elderly and strongly dose-related. Renal insufficiency, as judged by a raised blood urea concentration on admission, was not accompanied by an increase in side effects, confirming that frusemide does not carry major additional risks in renal failure. ${ }^{5}$

Volume depletion was noted in 85 recipients $(14.5 \%)$, which constitutes a substantially higher incidence than that $\left(5^{\circ} \%\right)$ reported by Greenblatt $e t a l^{6}$ using similar methodology. This was not due to differences in the degree of hypovolaemia reported, since the mean rise in blood urea concentration recorded in our study $(11.8 \mathrm{mmol} / 1 ; 71.1 \mathrm{mg} / 100 \mathrm{ml})$ was equivalent to a blood urea nitrogen concentration of approximately $12.5 \mathrm{mmol} / 1(35 \mathrm{mg} / 100 \mathrm{ml})$-that is, it was virtually identical with that observed in the other study. The difference in incidence was probably due to the higher daily doses of frusemide used in the Scottish hospitals, 347 patients $(59 \%$ ) being given $40 \mathrm{mg}$ daily and $160\left(27_{\%}^{\circ}\right) 80 \mathrm{mg}$ daily. In the study by Greenblatt et al $40^{\circ}$ o of recipients received less than $40 \mathrm{mg}$ daily and a further $36.5 \%$ between 35 and $55 \mathrm{mg}$ daily. In view of the potential seriousness of volume depletion their data suggest that, especially in elderly people, frusemide should begin at $20 \mathrm{mg}$ daily rather than $40 \mathrm{mg}$ daily.

Hyperuricaemia occurred in 54 patients $(9.2 \%)$. Nevertheless, only two of the 585 recipients developed symptoms of gout. The mechanism of frusemide-induced hyperuricaemia is controversial. It may be due to competition between the diuretic and urate for tubular excretory pathways, although there is no evidence for this. ${ }^{7}$ Alternatively it may be due to volume depletion consequent on sodium excretion. ${ }^{8}$ Were this correct we should expect to find not only a strong dose-response relation but also a relation between an increase in blood urea concentration and blood urate values. Both these relations were detected in our study.

Hypokalaemia was reported in only 21 patients $\left(3.6^{\circ}{ }_{0}\right)$, which agrees with the incidence in other series. ${ }^{6}$ The fall in serum potassium concentrations occurred independently of co-administered potassium supplements. No patient suffered overt symptoms from hypokalaemia, and in all cases the concentrations rose to normal on reducing the dose of diuretic and adjusting the intake of potassium in the diet. The relative independence between diuretic-induced hypokalaemia and potassium supplements was also observed by Greenblatt et $a l^{6}$ and by Lawson et al, ${ }^{9}$ who followed up a group of patients discharged from hospital taking diuretics for oedema. The second study showed no clear-cut relation between the onset of hypokalaemia and the use or lack of use of potassium supplements. Since potassium chloride supplements carry a risk of hyperkalaemia in about $3 \cdot 5^{\circ} \%$ of patients, ${ }^{10}$ we suggest that their use in hospital should be reserved for patients at maximum risk of hypokalaemia - that is, oedematous patients who develop a brisk diuresis shortly after beginning treatment.

Other adverse effects of frusemide were rare. Hyponatraemia, gastrointestinal upsets, and glycosuria are all well known but relatively rare accompaniments of frusemide use. Bullous skin eruption may occur after frusemide, though usually after high doses given to patients in renal failure. ${ }^{11}$ One case of ototoxicity has been reported ${ }^{12}$ but no such cases were observed in our study.

We conclude that frusemide is a safe and highly effective diuretic. Risks of volume depletion are apparently dose-related and may be reduced by beginning with a daily dose of 20 rather than $40 \mathrm{mg}$. The risks of hypokalaemia have been exaggerated in the past, and the justification for potassium supplements on a routine basis is by no means proved..$^{3}$

This work was carried out under the auspices of a grant from the Scottish Home and Health Department. We wish to thank Professor A Goldberg, Stobhill General Hospital, Glasgow, and the late Professor G M Wilson, Western Infirmary, Glasgow, for access to patients under their care; Dr H Jick for help and encouragement; and Dr D S Maclaughlin for computer facilities.

\section{References}

${ }^{1}$ Goodman, L S, and Gilman, A, The Pharmacological Basis of Therapeutics, 5th edn. New York, Macmillan, 1975.

2 Jick, H, et al, Fournal of the American Medical Association, 1970, 213, 1455.

3 Lawson, D H, and Jick, H, Fournal of Clinical Pharmacy, 1978, 3, 203.

${ }^{4}$ Hutcheon, A W, Lawson, D H, and Jick, H, fournal of Clinical Pharmacy, $1978,3,219$.

"Muth, R G, fournal of the American Medical Association, 1966, 195, 1066.

${ }^{6}$ Greenblatt, D J, et al, American Heart fournal, 1977, 94, 6.

${ }^{7}$ Bryant, J M, et al, American fournal of Medicine, 1962, 33, 400.

${ }^{8}$ Steele, T H, fournal of Laboratory and Clinical Medicine, 1969, 74, 288.

${ }^{9}$ Lawson, D H, et al, Quarterly Fournal of Medicine, 1976, 45, 469.

${ }^{10}$ Lawson, D H, Quarterly Fournal of Medicine, 1974, 43, 433.

$"$ Kennedy, A C, and Lyell, A, British Medical fournal, 1976, 1, 1509.

12 Mathog, R H, Thomas, W G, and Hudson, W R, Archives of Otolaryngology, 1970, 92, 7 .

${ }^{13}$ Kassirer, J P, and Harrington, J T, Kidney International, 1977, 2, 505.

(Accepted 28 fune 1979)

ONE HUNDRED YEARS AGO Mrs P, aged 23, a smart freshcomplexioned little woman, four feet two inches and a half in height, sought my assistance during her confinement. She was then in the eighth month of pregnancy. It should here be mentioned that she was delivered at full term with her first child, but so small was the pelvic capacity that my partner, who was then in attendance, was compelled to resort to craniotomy; but she recovered without a bad symptom. In June last year, she found herself enceinte, when she again sought advice. We then determined (knowing her previous history) to bring on abortion at the fifth month. This was done, and the foetus, living, delivered by version. A careful exploration was then made of the pelvis, which was found to be much narrowed in its transverse diameter, the symphysis pubes being angular and prominent; the sacral curve greatly exaggerated backwards, with a compensating spinal curvature in the dorsal region. The pelvic brim was abnormally large in its conjugate diameter, but the transverse would barely admit three fingers side by side. The patient was lost sight of till the beginning of January last, and when she found herself once more in the "interesting condition," and begged of me to try and bring her a live baby. This I promised to do if practicable, by inducing labour at the seventh month. When the appointed time arrived, I called with the view of making the necessary preparations for carrying out my plans, but found she had left the neighbourhood. However, on May 11th her husband came down, requesting my immediate attendance, as his wife was in strong labour; but before I could reach his house, he had returned, saying that "all was over," and that she had two little girls. On my arrival, I found to my astonishment that they had been expelled without any help whatsoever; the presentations being vertex and footling respectively. The children, although small, were fairly nourished, and showed no signs of inanition. The patient was up and about on the twelfth day, and when last visited, she and the children were in perfect health. Here we have another typical instance of nature's provisions in coping with our deformities by its wise manipulation in the subdivision of labour; for in this case, had it been that of a single birth, the fatal result to the child, if not to the mother also, would have been inevitable.-HUGH W Thomas. (British Medical fournal, 1879.) 